\title{
Penerapan Metode Active Debate untuk Meningkatkan Aktivitas Belajar pada Mata Kuliah Hubungan Internasional di Jurusan PPKn
}

\author{
Prayetno, Budi Ali Mukmin, Julia Ivanna, Ramsul Nababan
}

\author{
Jurusan Pendidikan Pancasila dan Kewarganegaraan, Fakultas Ilmu Sosial \\ Universitas Negeri Medan, Indonesia
}

Diterima September 2017; Disetujui November 2017; Dipublikasikan Januari 2018

\begin{abstract}
Abstrak
Penelitian ini merupakan penelitian tindakan kelas (PTK) yang bertujuan untuk meningkatkan aktivitas belajar mahasiswa pada mata kuliah hubungan internasional melalui metode active debate. Penelitian ini dilakukan di Jurusan PPKn, khususnya di kelas regular C dengan waktu penelitian dimulai pada bulan Juli sampai dengan bulan November tahun 2017. Penelitian ini menggunakan metode penelitian tindakan kelas (CAR) Class Action Researce yang berawal dari permasalahan yang muncul di dalam kelas. Teknik yang digunakan untuk pengumpulan data dalam penelitian ini menggunakan tes dan non tes. Tes yang diberikan berbentuk pilihan berganda dan non tes bersifat lembar obeservasi aktivitas kegiatan belajar mahasiswa. Hasil penelitian menunjukkan bahwa penerapan metode active debate memiliki pengaruh yang besar terhadap peningkatan aktivitas belajar dan dapat meningkatkan hasil belajar mahasiswa. Dalam hal peningkatan hasil belajar, penerapan metode active debate ini dapat meningkatkan hasil belajar dengan nilai rata-rata 86.6 pada siklus II. Sementara itu aktivitas belajar mahasiswa juga meningkat dengan menggunakan metode active debate ini. Hal itu dapat dilihat dari tujuh butir penilaian untuk melihat aktivitas belajar, yaitu keberanian dan semangat untuk mengungkapkan argumentasi; keterampilan dan kemampuan untuk bertanya: keterampilan dan kemampuan mahasiswa untuk menjawab; menyampaikan pendapat tentang materi; penalaran yang rasional dalam menyampaikan pendapat; aktif dan bertanggung jawab dalam selama proses; dan menghargai perbedaan pendapat. Semuanya mengalami yang signifikan. Dari data penelitian dapat dilihat dengan menggunakan model active debate respon mahasiswa pada mata kuliah Hubungan Internasional cenderung baik dan menyenangkan.
\end{abstract}

Keyword : Active debate, aktivitas belajar, Penelitian Tindakan Kelas

\begin{abstract}
This research is a classroom action research (PTK) that aims to increase student learning activities in the course of international relations through active debate method. This research was conducted in the Department of PPKn, especially in the regular C class with research time starting from July to November 2017. This research uses Class Action Researce classroom action research method which starts from problems that emerge in class. Technique used for data collection in this research using test and non test. The test given in the form of multiple choice and non test is obeservation sheet activity of student activity activity. The results showed that the application of active debate method has a great influence on the increase of learning activities and can improve student learning outcomes. In terms of improving learning outcomes, the application of active debate method can improve learning outcomes with an average value of 86.6 in cycle II. Meanwhile, student learning activities also increased by using this active debate method. It can be seen from seven points of assessment to see the learning activities, namely courage and spirit to express the argument; skills and ability to ask: skills and ability of students to answer; convey an opinion on the material; rational reasoning in expressing opinions; active and responsible during the process; and appreciate differences of opinion. Everything is significant. From the research data can be seen by using the model of active debate student response in the course of International Relations tend to be good and fun. Keyword: Active debate, learning activity, Classroom Action Research
\end{abstract}

How to Cite: Prayetno, Budi Ali Mukmin, Julia Ivanna, Ramsul Nababan (2018), Penerapan Metode Active Debate untuk Meningkatkan Aktivitas Belajar pada Mata Kuliah Hubungan Internasional di Jurusan PPKn, Anthropos: Jurnal Antropologi Sosial dan Budaya, 3 (2): 69-78

\begin{tabular}{lr}
\hline${ }^{*}$ Corresponding author: & p-ISSN 2460-4585 \\
E-mail: prayetnoppkn@gmail.com & e-ISSN 2460-4593
\end{tabular}




\section{PENDAHULUAN}

Merespon

kurikulum

Kerangka

Kualifikasi Nasional Indonesia (KKNI) yang diterapkan di Universitas Negeri Medan, upaya pembaharuan pembelajaran harus terus dilakukan agar mengarah kepada proses capaian pembelajaran yang menekankan pada pemusatan pembelajaran pada mahasiswa yang pada akhirnya akan bermuara pada pengembangan kemampuan berfikir kritis mahasiswa, munculnya keaktifan mahasiswa sehingga menciptakan sebuah iklim pembelajaran yang menyenangkan dan lebih menarik.

Sebagai intstusi LPTK yang akan melahirkan calon-calon guru, sudah selayaknya seorang dosen harus selalu melakukan berbagai inovasi dalam setiap proses pembelajaran sehingga para peserta didik yang kelak akan menjadi guru akan dapat mengambil inpirasi yang telah didapatkan dibangku perkuliahan kemudian diaplikasikan dalam proses pembelajaran di sekolah.

Di jurusan PPKn, Fakultas Ilmu Sosial Unimed, mata kuliah hubungan internasional merupakan mata kuliah wajib yang harus diambil pada semester ketiga. Mata kuliah Hubungan internasional merupakan Mata kuliah yang akan memperkenalkan dan melatihkan penggunaan konsep-konsep Hubungan internasional dalam mempresentasikan, menganalisis, dan menginter-pretasi fenomena hubungan internasional terutama dinamika hubungan internasional negara Indonesia. Oleh sebab itu mahasiswa akan dibekali konsep-konsep Mata tentang pengertian hubungan internasional; pendekatan dan ruang lingkup Hubungan Internasional; Teori-teori penting HI; Tujuan Mempelajari Hubungan Internasional; dan sejarah timbulnya hubungan Internasional; politik internasional; ekonomi politik internasional; konflik dan kerjasama antar negara; bentuk-bentuk dan dasar hubungan kerja sama antar negara; manfaat kerjasama dilihat dari kepentingan nasional; peran Indonesia dalam kerjasama antar negara; politik luar negeri Indonesia; diplomasi; implikasi globalisasi dan dampak yang ditimbulkannya bagi hubungan internasional; organisasi Internasional; isu-isu mutakhir hubungan internasional; dan perjanjian internasional.

Selama ini, proses pembelajaran pada mata kuliah Hubungan internasional telah menerapkan beberapa Metode pembelajaran yang menarik seperti penggunaan Metode Jigsaw, Metode Talking Stick, maupun penggunaan Metode snow ball untuk mengarahkan proses pembelajaran mengarah berpusat pada mahasiswa. Hanya saja, MetodeMetode yang telah diterapkan masih terasa kurang untuk meningkatkan aktivitas belajar dan kreatifitas mahasiswa sehingga mampu meningkatkan hasil yang maksimal dalam proses pembelajaran. Selain itu, penerapan Metode pembelajaran yang baru akan lebih memperkaya berbagai Metode pembelajaran. Seperti apa yang telah disebutkan dalam paragraf di atas, para mahasiswa yang kelak akan menjadi guru memiliki potensi besar akan meniru dosennya dalam proses pembelajaran. Oleh sebab itu, pengayaan berbagai Metode pembelajaran di bangku perkuliahan diharapkan akan dijadikan sebagai salah satu referensi bagi calon guru tersebut.

Penerapan metode active debate merupakan salah satu upaya yang digunakan untuk memperkaya motode-metode pembelajaran yang sudah dilakukan agar dapat meningkatkan aktivitas dan hasil pembalajaran khususnya pada mata kuliah hubungan internasional. Pemilihan metode active debate sebagai metode pembelajaran pada mata kuliah hubungan internasional didasarkan pada cakupan-cakupan materi pada mata kuliah tersebut sangat erat kaitannya dengan isu-isu hubungan internasional saat ini khususnya yang berkaitan dengan politik Indonesia. Selain itu, penerapaan metode active debate diharapakan agar mahasiswa dapat memahami konsep-konsep pada mata kuliah hubungan internasional.

\section{METODE PENELITIAN}

Metode yang akan digunakan dalam penelitian ini adalah penelitian tindakan kelas (PTK) atau yang dikenal dengan istilah 
Classroom action research (CAR) yang akan berfokus pada permasalahan di dalam kelas. Seperti apa yang dikatakan oleh Kemmis (dalam Sani dan Sudiran,2012; 2) penelitian tindakan kelas dilakukan melalui pengkajian atau inkuiri terhadap permasalahan dengan ruang lingkup dan situasi yang terbatas melalui refleksi diri. Pemilihan metode ini diharapkan mampu memperbaiki proses kegiatan pembelajaran yang dilaksanakan di dalam kelas dengan melakukan berbagai refleksi yang berawal dari penentuan tujuan pembelajaran, penyusunan materi pembelajaran, literatur yang akan digunakan, penentuan strategi pembelajaran sampai kepada penentuan alokasi waktu yang dibutuhkan.

Pendekatan partisipatif dan kolaboratif menjadi sebuah keharusan yang akan dilakukan dalam penelitian ini. Penelitian ini akan melibatkan beberapa dosen, maupun dengan mahasiswa sehingga akan sangat memungkin terciptanya ruang sharing dalam penyusunan dan penentuan perencanaan pembelajaran.

Tahapan penelitian ini menggunakan mengikuti alur berfikir yang dikembangkan oleh Kunto ( 2012 ; 11). Kunto memberikan argumentasi bahwa penelitian tindakan kelas terdiri dari emapat komponen yakni, tahapan perencanaan, tindakan, pengamatan sampai kepada tindakan refleksi. Oleh sebab itu, tahapan yang penelitian tindakan kelas tersebut akan menjadi sebuah satu siklus. Berikut ini adalah tahapan dari penelitian tindakan kelas tersebut.

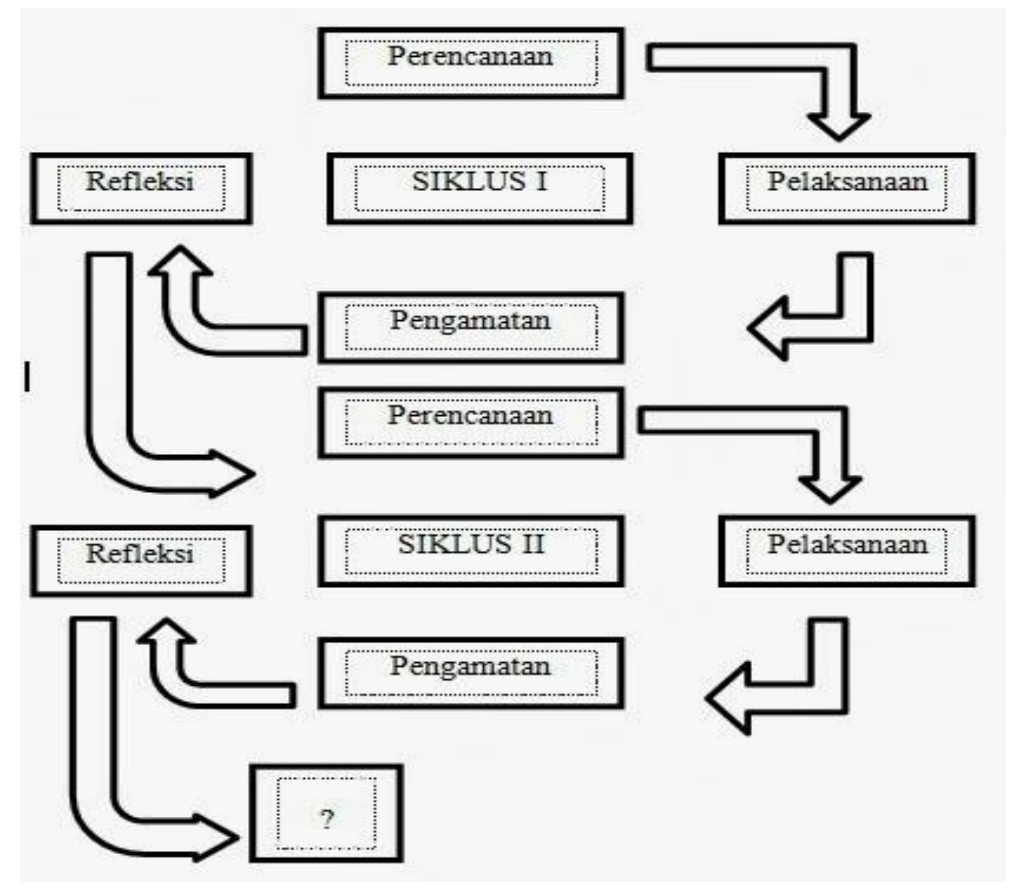

\section{HASIL DAN PEMBAHASAN}

Aktivitas Belajar

Aktivitas belajar merupakan hal yang tidak dapat dipisahkan dalam proses pembelajaran. Merujuk dengan kurikulum KKNI yang akan dilaksanakan di Universitas Negeri Medan, maka aktivitas belajar yang baik adalah aktivitas belajar yang mampu mengembangkan kreatifitas, mampu meningkatkan kemampuan berfikir mahasiswa yang sekaligus dapat meningkatkan hasil belajar dari mahasiswa itu sendiri. Meminjam argumentasi yang dikembangkan oleh Djamarah (2011; 38) bahwa aktivitas belajar bukanlah proses kehampaan dan tidak akan pernah sepi dari berbagai aktivitas. Djamarah juga memberikan argumentasi bahwa terdapat beberapa aktivitas belajar yang terdiri dari tahap mendengarkan, tahap memandang, tahap meraba, membau, mencicipi, menulis, membaca, membuat ringkasan, mengamati tabel atau diagram, menyusun paper, mengingat, serta mengigat. 
Di lain pihak, sardiman dengan tegas memberikan argumentasinya bahwa aktivitas belajar memiliki dua varian (Sardiman,2000;20). Pertama adalah dalam ruang lingkup yang lebih luas dimana kegiatan psiko-fisik menuju keperkembangan pribadi yang seutuhnya. Kedua, dalam arti sempit dapat dimaknai dengan suatu usaha penguasaan materi ilmu pengetahuan yang merupaka kegiatan menuju terbentuknya kepribadian seutuhnya.

Di dalam perkuliahan proses pembelajaran merupakan sebuah proses pengembangan keterampilan mahasiswa, pengembangan sikap, mentransformasikan aktivitas pengetahuan yang akan bermuara pada proses pembelajaran aktif. Menurut Ambarjaya (2012;123) pembelajaran aktif adalah segala bentuk pembelajaran yang memungkinkan perserta didik berperan secara aktif dalam proses pembelajaran itu sendiri baik dalam bentuk interaksi antar mahasiswa maupun mahasiswa dengan pengajar dalam proses pembelajaran tersebut. Dilain pihak Bonwell (dalam Ambarjaya,2012;124) lebih terperinci membagi karakteristik pembelajaran aktif tersebut.

Berikut ini adalah karakteristik pembelajaran yang dikemukakan oleh Bonwell.; a) Aktivitas Pembelajaran aktif itu menekankan proses pembelajaran bukan pada penyampaian informasi oleh pengajar, melainkan pengembangan keterampilan pemikiran analisis dan kritis terhadap topik atau permasalahan yang dibahas; b) Peserta didik tidak hanya mendengarkan materi pembelajaran secara pasif, tetapi mengerjakan sesuatu yang berkaitan dengan materi perkuliahan; c) Penekanan pada eksplorasi nilai-nilai dan sikap-sikap berkenaan dengan materi pembelajaran; d) Peserta didik lebih banyak dituntut untuk berpikir kritis, menganalisis, dan melakukan evaluasi; d) Umpan balik yang lebih cepat akan terjadi pada proses pembelajaran.

Dari uraian di atas maka kita dapat menarik sebuah kesimpulan, bahwa aktivitas pembelajaran yang baik adalah aktivitas yang tidak bersifat satu arah dimana dosen sebagai pusat pembelajaran, melainkan pembelajaran harus bersifat dua arah dan penekanan dalam proses pembelajaran harus lebih terfokus merangsang aktivitas dan kreatifitas mahasiswa sebagai upaya untuk pengembangan keterampilan, pengembangan sikap, pengembangan ilmu pengetahuan yang harapannya adalah tercapainya proses pembelajaran yang telah direncanakan. Oleh sebab itu, meminjam istilah yang digunakan oleh Hamalik $(2008 ; 12)$ pada dasarnya di dalam diri seseorang sudah terdapat prinsip aktif, yaitu keinginan untuk berbuat dan bekerja sendiri, tinggal bagaimana keterampilan dosen pengampu mata kuliah mendisaign pembelajaran agar lebih menarik dan interaktif.

Active debate merupakan salah dari metode dari pembelajaran active learning. Metode acitve debate merupakan rangkaian pembelajaran yang melibat beberapa orang yang terbagi ke dalam dua kelompo dimana di antara kelompok tersebut saling berbeda arugumentasi dalam menelaah sebuah kasus. Dilain fihak menurut Simon (dalam Pratiwi, 2012;9) bahwa debat merupakan rangkaian kegiatan bertukar fikiran antara dua orang atau lebih dimana masing-masing di antara mereka berusaha saling mempengerahui orang lain untuk menerima usul yang telah disampaikan. Pratiwi juga menambahkan bahwa debat juga dapat diterjemahkan sebagai silang pendapat tentang tema tertentu yang telah ditetapkan dimana dalam tema tersebut ada pihak yang mendukung atau pihak yang menolak melalui dialog formal yang terorganisir (Pratiwi, 2012;9).

Siberman (2009;127) memberikan sebuah argumentasi bahwa active debate merupakan suatu tekhnik perdebatan yang dapat dijadikan sebuah metode untuk mengembangkan pemikiran dari mahasiswa yang berbeda dengan pemikirannya mahasiswa yang lain. Selain dapat mengembangkan pemikiran mahasiswa, active debate dapat dijadikan sebagai refleksi dimana posisi argumentasi dari mahasiswa ketika mahasiswa tersebut memiliki perbedaan pandangan dalam sebuah kasus yang di perdebatkan. 
Metode active debate merupakan sebuah metode yang menitik beratkan kepada mahasiswa agar memiliki skills dalam mengungkapkan argumentasi, berfikir secara kritis, memiliki penguasaan materi yang dalam yang pada akhirnya akan dapat meningkatkan kemampuan akademik mahasiswa itu sendiri. Metode active Sdebate tampakanya selaras dengan kurikulum KKNI yang akan diterapkan di Universitas Negeri Medan, dimana spirit yang akan dibangun oleh kurikulum KKNI akan menekankan kepada proses pembelajaran yang berpusat kepada mahasiswa dan berpusat kepada proses pengembangan kemampuan mahasiswa itu sendiri.

Dalam mata kuliah Hubungan internasional, metode active debate merupakan suatu metode yang dapat merangsang mahasiswa agar aktif dalam proses pembelajaran bagi mahasiswa di kelas. Hal itu disebabkan karena pada mata kuliah Hubungan internasional terdapat beberapa kajian menarik untuk diperdebatkan, apalagi menyangkut dengan isu-isu hubungan internasional yang hangat di media televisi maupun di media massa saat ini. Hal ini senada dengan apa yang diungkapkan oleh Istarani (2012;83) yang mengatakan bahwa pembelajaran metode active debate sangat baik digunakan dalam rangka meningkatkan daya kritis dan analisis siswa terhadap suatu permasalahan.

Metode active debate digunakan dalam proses pembelajaran mata kuliah hubungan internasional nantinya akan diberikan isu-isu penting yang sedikit kontroversial sehingga akan menimbulkan adu argumentasi antara mahasiswa yang terbagi dalam dua kelompok. Dalam mengemukakan pendapat inilah mahasiswa dituntut harus mampu mengeluarkan gagasan atau ide-ide nya yang kuat yang berasal dari sumber-sumber materi yang telah disajikan pada mata kuliah hubungan internasional. Disinilah peranan penting dosen pengampu mata kuliah harus mampu mengarahkan debate antara dua kelompok mahasiswa tersebut agar sesuai dengan tujuan pembelajaran yang ingin dicapai.

Jika dilihat secara keseluruhan, maka metode active debate ini memiliki beberapa kelebihan jika diterapkan dalam proses pembelajaran. Berikut ini adalah beberapa kelebihan metode active debate jika diterapkan dalam proses pembelajaran (Istarani,2012;8485): a) Metode active debate dapat meningkatkan daya kritis berfikir siswa; b) Metode active debate dapat meningkatkan kemampuan siswa untuk mengemukakan pendapat di depan orang banyak; c) Dapat meningkatkan kemampuan mahasiswa untuk memahami pola fikir orang lain yang tidak sesuai dengannya; d) Dapat menggali ide-ide atau gagasan cemerang dari siswa; e) Dapat melatih mahasiswa hidup harmoni dengan orang bersebrangan dengannya.

Untuk lebih lengkapnya, Silberman (2013;141) memberikan prosedur-prosedur metode active debate yang harus dilakukan ketika ingin diterapakan dalam proses pembelajaran. Tahapan-tahapan tersebut adalah; 1) penentuan tema oleh desen, 2) pembagian kelompok dan sub kelompok pro dan kontra oleh dosen, 3) pengaturan bangku posisi kelompok pro dan kontra berhadapan, 4) memulai aktivitas debate dengan penyampaian argumentasi masing masing kelompok terhadap tema, 5) tanggapan dan pertanyaan dari argumentasi yang disampaikan oleh masingmasing kelompok, 6) refleksi oleh desen dengan membentuk lingkaran, 7) kesimpulan oleh dosen.

Berdasarkan penelitian yang dilakukan menunjukkan ada perbedaan signifikan antara aktifitas dan hasil belajar dan hasil belajar pada siklus I dan siklus II. Perbedaan tersebut dapat dilihat dari penjelasan tabel dibawah ini.

Hasil pengamatan pada siklus I terhadap aktifitas belajar mahasiswa pada mata kuliah Hubungan Internasional menunjukkan; 
Prayetno, Budi Ali Mukmin, Julia Ivanna, Ramsul Nababan, Penerapan Metode Active Debate untuk

Pengamatan Aktivitas Belajar Active Debate Siklus I

\begin{tabular}{|c|c|c|}
\hline Tindakan Siklus I & Proses Pembelajaran Active Debate & Active Debate Mahasiswa \\
\hline $\begin{array}{l}\text { Kondisi kelas } \text { belum } \\
\text { ditata, belum tercipta } \\
\text { kondisi yang mendukung } \\
\text { pembelajaran. }\end{array}$ & $\begin{array}{l}\text { Dosen selalu memeriksa kehadiran dan } \\
\text { memotivasi mahasiswa. } \\
\text { Dosen Selalu menjelaskan tujuan dan manfaat } \\
\text { pembelajaran di awal perkuliahan }\end{array}$ & $\begin{array}{l}\text { Mahasiswa belum memiliki } \\
\text { kemampuan yang baik dalam } \\
\text { melakukan kegiatan awal } \\
\text { perkuliahan yakni kegiatan } \\
\text { apersepsi }\end{array}$ \\
\hline $\begin{array}{l}\text { Dosen menyiapkan } \\
\text { Perangkat Pembelajaran }\end{array}$ & $\begin{array}{l}\text { Menjelaskan alur kegiatan perkuliahan yang } \\
\text { akan dilakukan } \\
\text { Mengajukan pertanyaan awal/permasalahan } \\
\text { Menggunakan alat bantu (media) pembelajaran } \\
\text { yang sesuai dengan tujuan dan materi } \\
\text { pembelajaran untuk active debat } \\
\text { Berperan sebagai fasilitator dalam active debate } \\
\text { Memberi penjelasan dan petunjuk yang } \\
\text { berkaitan dengan isi pembelajaran active debate } \\
\text { Mengarahkan dan memandu model } \\
\text { pembelajaran active debate } \\
\text { Memantapkan penguasaan materi pembelajaran } \\
\text { tentang politik luar negeri Indonesia yakni; a) } \\
\text { Pengertian, tujuan, peranan, dan hal-hal yang } \\
\text { mempengaruhi politik luar negeri bebas aktif } \\
\text { dalam percaturan politik internasional. b) } \\
\text { Dinamika politik luar negeri indonesia di } \\
\text { kawasan regional. c) Politik luar negeri } \\
\text { indonesia terhadap negara tetangga (malaysia). } \\
\text { Memberikan umpan balik dari proses active } \\
\text { debate }\end{array}$ & $\begin{array}{l}\text { Penguasaan materi } \\
\text { pembelajaran sudah baik, } \\
\text { hanya saja mahasiswa } \\
\text { kurang memiliki keberanian } \\
\text { untuk berargumentasi dalam } \\
\text { aktivitas active debate. } \\
\text { Aktivitas komunikasi umpan } \\
\text { balik dalam Proses active } \\
\text { debate kurang berjalan } \\
\text { dengan baik. } \\
\text { Aktivitas mahasiswa dalam } \\
\text { menanggapi materi active } \\
\text { debate belum begitu baik } \\
\text { Proses menghargai pendapat } \\
\text { dalam activitas debate belum } \\
\text { tercipta. } \\
\text { Penguasaan dan pengelolaan } \\
\text { kelas masih kurang. }\end{array}$ \\
\hline $\begin{array}{l}\text { Mahasiswa fokus dan } \\
\text { memperhatikan } \\
\text { penjelasan dari dosen } \\
\text { setelah model active } \\
\text { debate berlangsung }\end{array}$ & $\begin{array}{l}\text { Menyimpulkan kegiatan pembelajaran dan } \\
\text { memberi penilaian hasil kerja mahasiswa }\end{array}$ & $\begin{array}{l}\text { Kegiatan penutup belum } \\
\text { melibatkan mahasiswa } \\
\text { dalam menyimpulkan materi } \\
\text { pembelajaran }\end{array}$ \\
\hline
\end{tabular}

Rerata Aktivitas Belajar Siklus I

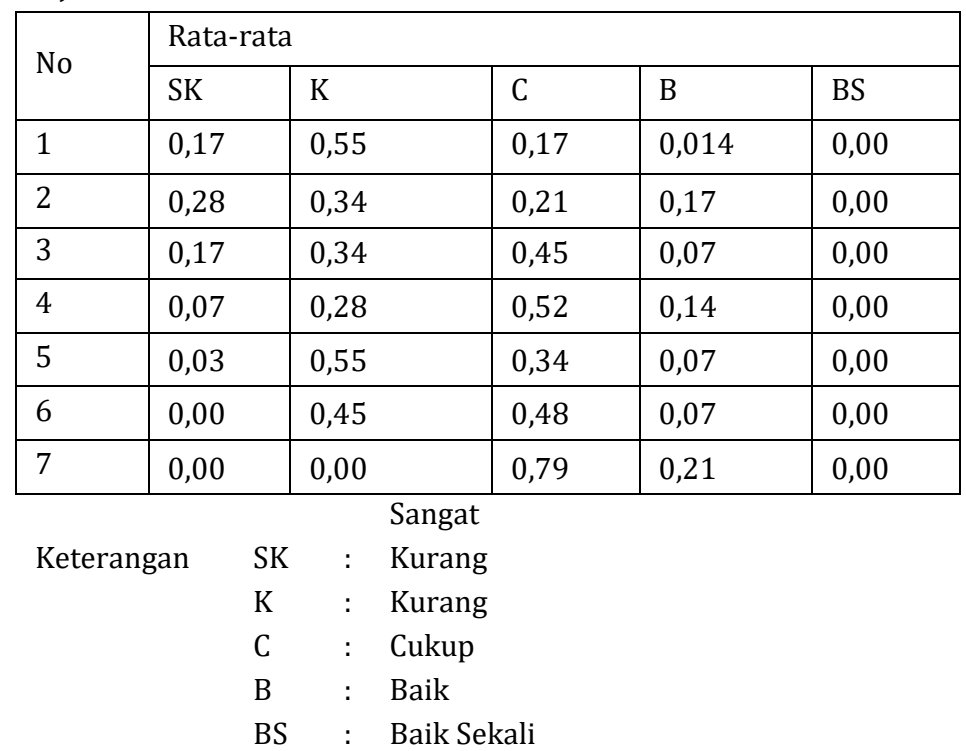


Sementara itu, hasil pengamatan pada pada mata kuliah Hubungan Internasional siklus II terhadap aktifitas belajar mahasiswa menunjukkan;

Pengamatan Proses Pembelajaran Active Debate Siklus II

\begin{tabular}{|c|c|c|}
\hline Tindakan Siklus II & Proses Pembelajaran Active Debate & Active Debate Mahasiswa \\
\hline $\begin{array}{lrr}\text { Kondisi } & \text { kelas } & \text { sudah } \\
\text { tertata, tercipta } & \text { kondisi } \\
\text { yang } & \text { mendukung } \\
\text { pembelajaran. }\end{array}$ & $\begin{array}{l}\text { Dosen selalu memeriksa kehadiran dan } \\
\text { memotivasi mahasiswa. } \\
\text { Dosen Selalu menjelaskan tujuan dan } \\
\text { manfaat pembelajaran di awal perkuliahan }\end{array}$ & $\begin{array}{l}\text { Mahasiswa sudah memiliki } \\
\text { kemampuan yang baik dalam } \\
\text { melakukan kegiatan awal model } \\
\text { active debate }\end{array}$ \\
\hline $\begin{array}{l}\text { Dosen menyiapkan } \\
\text { Perangkat Pembelajaran }\end{array}$ & $\begin{array}{l}\text { Menjelaskan alur kegiatan perkuliahan } \\
\text { yang akan dilakukan } \\
\text { Mengajukan } \\
\text { awal/permasalahan } \\
\text { Menggunakan alat bantu (media) } \\
\text { pembelajaran yang sesuai dengan tujuan } \\
\text { dan materi pembelajaran untuk active } \\
\text { debat } \\
\text { Berperan sebagai fasilitator dalam active } \\
\text { debate } \\
\text { Memberi penjelasan dan petunjuk yang } \\
\text { berkaitan dengan isi pembelajaran active } \\
\text { debate memandu model } \\
\text { Mengarahkan dan man man } \\
\text { pembelajaran active debate } \\
\text { Memantapkan penguasaan materi } \\
\text { pembelajaran materi tentang ekonomi } \\
\text { politik internasional, perdagangan } \\
\text { internasional unan balik dari proses } \\
\text { Memberikan umpan } \\
\text { active debate }\end{array}$ & $\begin{array}{l}\text { Penguasaan materi pembelajaran } \\
\text { sudah baik, dan mahasiswa sudah } \\
\text { memiliki keberanian untuk } \\
\text { berargumentasi dalam aktivitas } \\
\text { active debate. } \\
\text { Aktivitas komunikasi umpan balik } \\
\text { dalam Proses active debate } \\
\text { berjalan dengan baik. } \\
\text { Aktivitas mahasiswa dalam } \\
\text { menanggapi materi active debate } \\
\text { sudah terlihat aktif } \\
\text { Proses menghargai pendapat } \\
\text { dalam activitas debate sudah } \\
\text { tercipta. } \\
\text { Penguasaan dan pengelolaan kelas } \\
\text { sudah kondusif. }\end{array}$ \\
\hline $\begin{array}{l}\text { Mahasiswa fokus dan } \\
\text { memperhatikan } \\
\text { penjelasan dari dosen } \\
\text { setelah model active } \\
\text { debate berlangsung }\end{array}$ & $\begin{array}{l}\text { Menyimpulkan kegiatan pembelajaran dan } \\
\text { memberi penilaian hasil kerja mahasiswa }\end{array}$ & $\begin{array}{l}\text { Kegiatan penutup melibatkan } \\
\text { mahasiswa dalam menyimpulkan } \\
\text { materi pembelajaran }\end{array}$ \\
\hline
\end{tabular}

Rerata Aktivitas Belajar Siklus II

\begin{tabular}{|c|c|c|c|c|c|}
\hline \multirow{2}{*}{ No } & \multicolumn{5}{|c|}{ Rata-rata } \\
\hline & SK & $\mathrm{K}$ & $\mathrm{C}$ & B & BS \\
\hline 1 & 0,00 & 0,00 & 0,03 & 0,72 & 0,24 \\
\hline 2 & 0,00 & 0,00 & 0,07 & 0,69 & 0,24 \\
\hline 3 & 0,00 & 0,00 & 0,03 & 0,76 & 0,21 \\
\hline 4 & 0,00 & 0,00 & 0,07 & 0,66 & 0,28 \\
\hline 5 & 0,00 & 0,00 & 0,07 & 0,76 & 0,17 \\
\hline 6 & 0,00 & 0,00 & 0,07 & 0,76 & 0,17 \\
\hline 7 & 0,00 & 0,00 & 0,03 & 0,59 & 0,34 \\
\hline
\end{tabular}

$\begin{array}{llll}\text { Keterangan } & \text { SK } & : & \text { Sangat Kuran } \\ & \text { K } & : & \text { Kurang } \\ \text { C } & : & \text { Cukup } \\ & \text { B } & : & \text { Baik } \\ & \text { BS } & : & \text { Baik Sekali }\end{array}$


Sedangkan hasil belajar mahasiswa pada mata kuliah Hubungan Internasional dengan menggunakan model aktive debate dapat dilihat setelah dilakukan kegiatan Siklus I dan Siklus II. Peneliti dapat membandingkan
Hasil yang diperoleh yang dimulai dari kegiatan hasil belajar yang dapat dilihat dari pre test maupun dari post test. Berikut ini adalah hasil perbandingan pre test dan post test pada siklus I dan siklus II

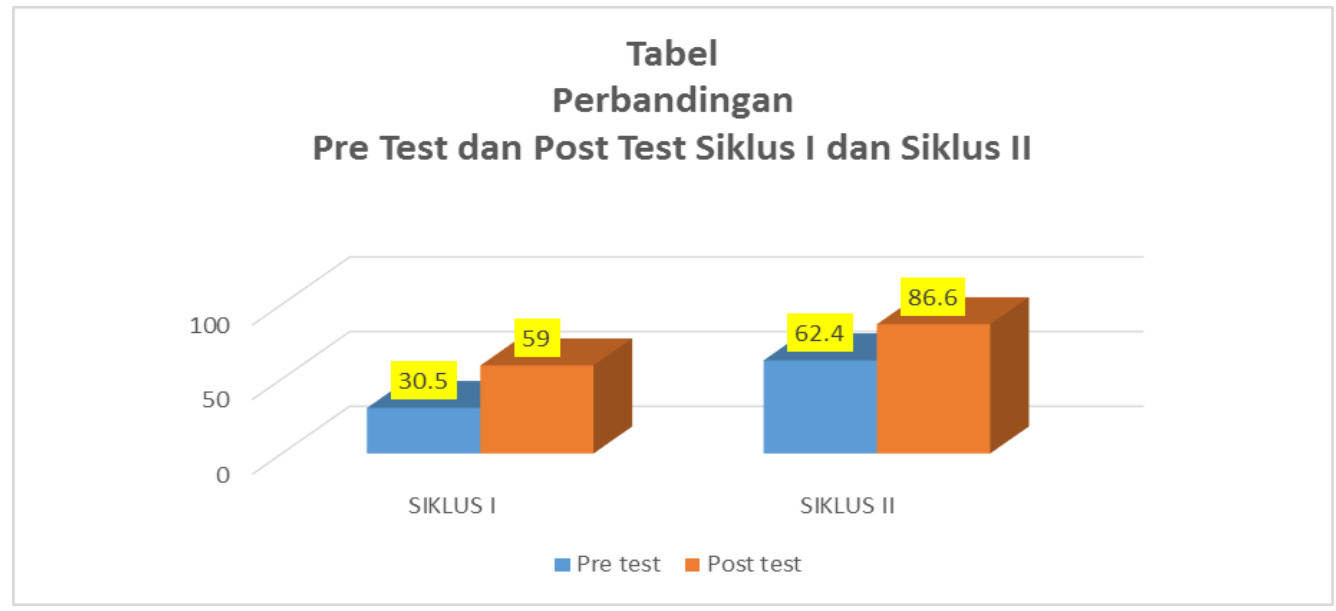

Grafik 1. Perbandingan tabel Pre Test dan Post Test Siklus I dan Siklus II

Berdasarkan hasil penelitian dan pengamatan selama penelitian ini menunjukkan bahwa proses pembelajaran mata kuliah Hubungan Internasional dengan menggunakan model active debate sangat menyenangkan. Hal tersebut dapat dilihat dari aktivitas pembelajaran mahasiswa di dalam kelas cukup aktif. Aktivitas pembelajaran mahasiswa yang tinggi ternyata berbanding lurus dengan hasil belajar yang diperoleh oleh mahasiswa dimana hal itu dapat dilihat penilaian pre test maupun hasil post test yang mereka dapatkan.

Pada siklus I, aktivitas mahasiswa dalam proses pembelajaran sudah mulai meningkat, hanya saja masih banyak mahasiswa yang kurang berpartisipasi aktif dalam pelaksanaan model active debate tersebut. Hal ini dapat dimaklumi mengingat rata-rata mahasiswa yang ada di dalam kelas belum terbiasa dan belum memahami secara baik pembelajaran dengan menggunakan model active debate tersebut dan suasana kelas cenderung kurang kondusif. Jika dilihat dari hasil belajar yang didapatkan dengan menggunakan model tersebut, masih terkategori masih rendah. Indikasi itu dapat dilihat dari hasil pre tes yang didapatkan ratarata 30,5 dan hasil post tes yang mereka dapatkan pada siklus rata-rata 58,8. Faktor utama rendahnya hasil tersebut dikarenakan peneliti masih kurang dalam memberikan materi secara merata dan kurang mengelola waktu dan kelas secara baik dan suasana kelas yang tidak kondusif

Peningkatan signifikan terjadi pada tidankan siklus II yang dapat dilihat aktivitas maupun dilihat dari hasil belajar yang mereka peroleh. Hasil belajar yang diperoleh mahasiswa pada siklus II cenderung meningkat. Pre tes pada siklus II hasil belajar mahasiswa rata-rata 62,4 sedangkan hasil post test yang diperoleh mahasiswa rata-rata 86,6. Ini membuktikan bahwa refleksi yang digunakan peneliti untuk penyempurnaan penyamapaian materi secara merata dalam proses perkulihan sangat efektif dan keadaan kelas dapat dikendalikan dengan baik sehingga konsentrasi serta tanggung jawab mahasiswa ketika debat berlangsung dapat terlihat.

Jika dilihat dari aktivitas belajar mahasiswa, maka dapat terlihat perbedaan yang sangat signifikan antara siklus I dan siklus II. Pada butir pertama "Keberanian mahasiswa dan semangat untuk berani berargumentasi dalam active debate" siklus I keberanian mahasiswa masing kurang dengan rata-rata 0.55. Salah satu penyebab rendahnya keberanian tersebut dikarenakan terbiasanya 
mahasiswa untuk saling berdebat dan berbeda argumentasi. Pada siklus II, keberanian dan semangat mahasiswa untuk berargumentasi terkategori baik dengan rata-rata 0.72 , bahkan terdapat mahasiswa yang sudah sangat berani dengan kategori baik sekali dengan rata-rata 0.24 .

Pada butir kedua yang berkaitan tentang keterampilan dan kemampuan untuk bertanya dalam active debate masih kurang dengan rata-rata $0.34 \%$. Sedangkan pada siklus II keterampilan tersebut meningkat sangat signifikan dengan rata-rata $0.69 \%$, bahkan ada beberapa mahasiswa yang keterampilannya terkategori baik sekali dengan rata-rata $0.24 \%$. Salah satu indikator meningkatnya keterampilan mahasiswa tersebut adalah mahasiswa memahami materi yang disajikan dalam active debate sehingga mahasiswa memahami secara baik tema-tema yang sedang diperdebatkan.

Pada butir ketiga yang berkaitan tentang keterampilan dan kemampuan mahasiswa untuk bertanya masih terkategori cukup dengan rata-rata 0.45 . Pada siklus ke II, keterampilan dan kemampuan mahasiswa untuk menjawab dalam active debate meningkat dengan kategori baik dengan nilai rata-rata $0.76 \%$. Sama halnya dengan kemampuan bertanya pada grafik sebelumnya, bahwa penguasaan materi yang baik ternyata memberikan sumbangsih yang besar bagi mahasiswa untuk menjawab ketika debate berlangsung.

Pada butir keempat, keterampilan dan kemampuan argumentasi mahasiswa yang tersusun secara sistematis masih terkategori cukup dengan rata-rata persentasi $0.52 \%$ pada siklus I. Sedangkan pada siklus II, argumentasi mahasiswa yang tersusun secara sistematis sangat meningkat dimana indikasi itu dapat dilihat dari rata-rata baik dengan 0.66\%. Ketepatan penyamapaian materi yang diperdebatkan menjadi faktor utama keberhasilan pada butir ini. Faktor pendukung yang lain keberhasilan pada butir ini adalah cara penyampaian materi yang dilakukan peneliti kepada mahasiswa dilakukan secara perlahan dan materinya dapat didukung dengan contoh-contoh yang kongkrit.

Pada butir kelima yang berkaitan tentang penguasan materi dan ketepatan penalaran yang rasional dalam menyampaikan materi pendapat mengalami peningkatan pada siklus II dengan penguasaan materi dengan rata-rata $0.76 \%$ terkategori baik. Jika dibandingkan pada siklus I hanya $0.55 \%$, maka hal ini menunjukkan perubahan yang sangat signifikan. Perubahan pada tahap refleksi siklus I, dimana tim peneliti mulai memberikan pengarahan materi secara merata kepada mahasiswa yang dibantu dengan alat pengeras suara, berimbas kepada penguasaan materi mahasiswa meningkat.

Hal yang sama juga terjadi pada pada butir keenam pada aktivitas belajar yang berkaitan berkaitan tentang aktivitas aktif dan bertanggung jawab dalam proses perdebatan. Pada siklus ke II hal tersebut menjadi baik dengan skor $0.76 \%$ lebih baik dari siklus I yang terkategori cukup dengan $0.48 \%$. Hal senada juga terjadi pada buti ketujuh yang berkaitan tentang proses menghargai perbedaan pendapat dalam proses active debate.

Jika siklus I, proses menghargai pendapat yang saling berbeda kurang terlihat karena masing-masing kelompok terbawa dengan perasaan emosional untuk mempertahankan argumentasinya tanpa mempertimbangkan argumentasi yang dibangun oleh kelompok lain. Oleh sebab itu, pada siklus I proses untuk saling menghargai perbedaan pendapat terkategori cukup dengan rata-rata $0.79 \%$, sedangkan pada siklus II kategori cukup sudah berkurang dan sudah terkategori baik dengan rata-rata 0.59\%.

Adanya peningkatan aktivitas belajar dan meningkatnya hasil belajar siswa pada siklus II, dikarenakan adanya upaya perubahanperubahan ataupun upaya perbaikan yang dilakukan oleh tim peneliti pada tindakan siklus I. Kegiatan refleksi yang dilakukan oleh tim peneliti pada siklus I menjadi pintu masuk untuk memperbaiki beberapa kelemahan yang terdapat pada siklus I dan diaplikasikan pada tindakan siklus II. 


\section{KESIMPULAN}

Dari hasil penelitian yang dilakukan di Jurusan PP-Kn khususnys di Kelas Reguler C angkatan 2016 pada mata kuliah Hubungan Internasional bahwa aktivitas belajar mahasiswa dan hasil belajar mahasiswa mengalami peningkatan. Suasana kelas menjadi hidup dan tetap kondusif. Dari segi penguasaan materi, mahasiswa di kelas Reguler C mampu menguasai dan menyerap meteri yang diberikan oleh tim peneliti. Sama halnya dengan peningkatan aktivitas mahasiswa di dalam kelas. Aktivitas pemebelajaran tidak lagi terpusat pada seorang dosen, melainkan terpusat kepada mahasiswa. Indikasi keterlibatan aktif mahasiswa dalam kelas ini dapat dilihat dari perdebatan antara mahasiswa yang tergabung dalam kelompok "pro" maupun kelompok "kontra". Imbas besar dari aktifnya mahasiswa dalam proses pembelajaran pada mata kuliah Hubungan Internasional adalah hasil belajar mahasiswa mengalami peningkatan. Penguasaan materi yang baik merupakan salah satu faktor besar yang mendukung mahasiswa mampu menjawab pertanyaan-pertanyaan yang diberikan baik dalam bentuk pre test maupun dalam bentuk post tes.

Keberhasilan tim peneliti dalam penelitian ini tak terlepas dari refleksi yang dilakukan pada siklus I. Upaya untuk mengatur dalam hal pengelolaan waktu debat, penjelasan materi yang merata kepada mahasiswa, serta melakukan pengelolaan kelas yang baik merupakan beberapa langkah tepat untuk meningkatkan aktivitas dan hasil belajar mahasiswa

\section{DAFTAR PUSTAKA}

Ambarjaya, S B. 2012. Psikologi Pendidikan dan Pengajaran Teori dan Praktik. Yogyakarta. Penerbit CAPS.

Arikunto, S. 2006. Prosedur Penelitian Suatu Pendekatan Praktik. Jakarta. Rineka Cipta.

Hamalik, O. 2008. Proses Belajar Mengajar. Bandung. Sinar Baru.

Hidayah N. et,all. 2008. Media Visual Sebagai Penunjang Pembelajaran Kooperatif Pada Mata Kuliah Dasar-Dasar Hubungan internasional. Sebuah penelitian di Program Studi Pendidikan Sejarah. Universitas Yogyakarta.

Istarani. 2012. 58 Model Pembelajaran Inovatif. Medan. Media Persada

Sani, A, R dan Sudiran. 2012. Penelitian Tindakan Kelas. Medan. Perdana Mulya Sarana.

Sardiman. A.M. 2000. Interaksi dan Motivasi Belajar Mengajar. Jakarta: PT Raja Grafindo Persada.

Silberman, Mel. 2013. Active Learning 101 Strategi Pembelajaran Aktif. Yogyakarta. Putaka Insan Madani.

Pratiwi, Eka A, I. 2012. Peningkatan keterampilan Berbicara Dengan Metode Debat Plus dalam Proses Pembelajaran Bahasa Inggris Pada Siswa Kelas XI IPA SMA Parawisata Kertha Wisata Denpasar. Thesis. Pascasarjana. Denpasar. Universitas Udayana.

Robert Jackson \& George Sorensen, Pengantar Studi Hubungan Internasional, Jakarta, Pustaka pelajar, 2005. (6.34) 